\title{
International Migration and Human Security and Development in Mongolia
}

\author{
Tsuneo Akaha \\ Professor, Middlebury Institute of International Studies at Monterey, USA
}

\section{Introduction}

$\mathrm{I}$ nternational migration is a global phenomenon and an integral part of ever-expanding phenomenon of globalization. According to International Migration Report 2015, the number of international migrants worldwide had grown rapidly over the preceding fifteen years and reached 244 million in 2015, up from 222 million in 2010 and 173 million in $2000 .{ }^{1}$ Nearly two thirds of all international migrants worldwide lived in Europe or Asia, the latter hosting 75 million international migrants in 2015. Between 2000 and 2015, Asia added more international migrants than any other major area of the world, receiving about 26 million new international migrants. This represented 1.7 million additional migrants each year. ${ }^{2}$ Northeast Asia, including China, Taiwan, Japan, Korea, Mongolia, and Russia, was and remains a part of the dynamic global migration phenomenon. In terms of impact on global migration, however, the significance of the regional countries ranges widely, from China, which is the most significant, to North Korea and Mongolia, the least significant. China, with its huge population of 1,378 million persons in mid-2016 is both an important source and destination of international migration with a net migration (immigration minus emigration) of near zero. North Korea has a rather small population (25.1 million persons in mid-2016) and a small net migration loss

\footnotetext{
International Migration Report 2015: Highlights, New York: United Nations, 2016, p. 1. Available from http://www.un.org/en/development/desa/population/migration/publications/ migrationreport/docs/MigrationReport2015_Highlights.pdf (accessed June 15, 2017).

2 Ibid., p. 6.
}

This article is published under the Creative Commons CC-BY-ND License (http://creativecommons.org/licenses/by-nd/4.0/). This license permits use, distribution and reproduction, commercial and non-commercial, provided that the original work is properly cited and is not changed anyway. 
(more emigration than immigration), but the refugees (most often referred to as "defectors") who leave the country each year, though small in number, represent an important human rights concern to the international community because of the human rights abuses they typically experience in their own country and also often at their transit points and destinations. Mongolia has the smallest population in the region (3.1 million persons in mid-2016) and its net migration (immigration minus emigration) is near zero. ${ }^{3}$

In this brief analysis, we will examine the international migration situation in Mongolia, placing the country in the regional context, in order to identify the opportunities and challenges that international migration presents to the country and the migrants who cross its borders. Even though international migration is a global phenomenon, our focus on the regional context is warranted by the fact that it is the movement of people between Mongolia and its neighbors that represent the most significant migration-related impact and implications for Mongolia and its people. International migration is a multidimensional phenomenon and our full understanding requires a multidisciplinary approach drawing theoretical, methodological, and empirical insights from economics, sociology, demography, anthropology, geography, history, legal studies, political science, international relations, and security studies. In this study, however, we will focus on the human security and human development aspects of international migration in Mongolia. This will allow us to capture and highlight the impact of the cross-border flows of people on the people of Mongolia and on the border-crossing individuals themselves.

Before we look at the international migration situation in Mongolia, we need to lay out the key concepts we will employ in this study, i.e., "migration," "human security," and "human development." Not only is it important to have a common understanding of these terms as far as the present analysis is concerned, but defining these terms will also point us to the particular aspects of international migration in Mongolia that will be the focus of this analysis. It will also indicate the scope and limits of the present study.

\section{Migration, Human Security, and Human Development}

"Migration" includes internal migration and international migration, but in this study we will focus primarily on international migration, i.e., the flow of people across Mongolia's national borders. People migrate for different reasons

UN Population Reference Bureau, 2016 World Population Data Sheet with a Special Focus on Human Needs and Sustainable Resources, New York: UN Population Reference Bureau, 2016, p. 13, downloadable as http://www.prb.org/pdf16/prb-wpds2016-web-2016.pdf (accessed June $15,2017)$. 
and purposes and their movement has both intended (foreseen) and unintended (unforeseen) consequences. This study will include discussion of labor migration, refugees, human trafficking, and other types of migration, each with different implications for human security and human development.

The International Organization for Migration (IOM) and other international agencies define "migrant" as someone who has lived in a country other than her/his country of regular residence or citizenship. This definition applies to both "legal" (regular) and "illegal" (irregular or undocumented) migrants. Statistics on the latter category of migrants are all estimates and naturally differ from the actual number of foreign nationals. Also, the legal status of migrants, particularly that of those who are outside of their country of citizenship or usual residence for extended periods of time, changes over time. For example, students may become workers, legal migrant workers may become illegal labor migrants by overstaying their visas, and undocumented migrants may become asylum-seekers or refugees. Moreover, a person who may qualify as a "migrant" or "refugee" in one country may not be recognized as such in another country because countries apply different legal definitions and operational standards for non-nationals within their territory. Moreover, most of the human trafficking around the world goes undetected and therefore, statistics on victims of human trafficking are estimates and difficult to verify. Therefore, we need to use statistics on migrants, refugees, asylum seekers, and victims of human trafficking with caution and flexibility.

In this study, we are particularly interested in the human security and human development aspects of migration. "Human security" refers to the security of individual persons, in contrast to "national security," and has three components: freedom from want, freedom from fear, and freedom to live with human dignity. Each of these components, or pillars, can and has been operationalized differently but in this study we will employ a widely accepted, if not perfect, indicator for each of them as it helps us gauge the level of human security people enjoy, or the depth or seriousness of the threats they live under in terms of the three pillars of human security. Obviously, the level of human security (or insecurity) varies from people to people or from area to area within a country, the study of international migration has generally established that international migrants, including the various categories of border-crossing persons noted above, are particularly vulnerable to human security threats because they are away from home and live outside of the effective limits of their government's physical or legal protections and often find themselves beyond the protections of the governments of their host countries. Although legitimate national security concerns do arise in international migration, such as with respect to the breach of national borders, terrorism, trafficking in persons, drugs, and arms, and other 
forms of threats to public order and security that may be posed by bordercrossing individuals, this study will emphasize the human security of migrants, including labor migrants, asylum-seekers, refugees, and victims of human trafficking, as these are some of the most vulnerable individuals with respect to the three pillars of human security.

Until recently, within the field of migration studies, "development" generally meant "economic measures of development," i.e., quantitative increases and qualitative improvements in the material assets migration brings or is expected to bring to the countries of origin and of destination, as well as to the migrants, their families, and their communities, such as income, employment skills and opportunities, consumption, remittances, savings, and tax. It is beyond the scope of this brief analysis to describe the various contributions that economists have made to the study of migration. ${ }^{4}$ Suffice it to point out that their primary focus has been those aspects of migration that can be captured by quantitative data, remittances being the prime example. "Brain drain" has also been a popular subject of economic inquiry in the study of the migration-development nexus. Although some economic studies have pointed out uneven impacts of migration generally and remittances specifically on economic development at home and at destination, they have generally shown that the net impact of international migration is positive. They have also pointed out that the benefits and costs of international migration are unevenly distributed within the origin and destination communities/countries, giving rise to both voices for more liberal migration policy and advocacies for tighter migration control. In order to enhance the positive developmental impact of international migration, advocates have urged the international community to encourage developing countries to see integrate migration as an integral part of their national development strategy, ${ }^{5}$ and their recommendation has found its way into the 2030 Agenda for Sustainable Development adopted in 2015 by the United Nations Summit. ${ }^{6}$

Another approach to development that has direct relevance to the study

For a recent example of a study of migration's contribution to economic development, see Asia-Pacific Migration Report 2015: Migrants' Contributions to Development, ST/ ESCAP/2738, United Nations Economic and Social Commission for Asia and the Pacific, 2015.

5 See, for example, International Migration Report 2015; Global Forum on Migration \& Development, "Ninth GFMC - 2016, Concept Paper for Third Thematic Workshop on Migration for Peace, Stability, and Growth," UN HA, New York, July 19, 2016; Peter Sutherland, "Migration Is Development: How Migration Matters to the Post-2015 Debate." Available from https://esa.un.org/unmigration/Migration_is_Development_by_PSutherland MPP.pdf (accessed June 15, 2017).

6 United Nations, "Sustainable Development Goals: 17 Goals to Transform Our World." Available from http://www.un.org/sustainabledevelopment/development-agenda/. 
of migration, including the present analysis, is that of "human development." Whereas the traditional concept of "development" relates more closely to the macro-level development of an entire country, typically captured by GDP or its growth rate, "human development" refers to the development of an individual person's potential as a human being and the familial or community context within which the individual's potential is or is not being realized. The concept has been developed and elaborated to the point where countries can be compared according to how their people's human development stands relative other countries or how the level of human development of the same country changes overtime. Human development index (HDI) is used for comparative purposes. It is "a summary measure of average achievement in key dimensions of human development: a long and healthy life, being knowledgeable, and have a decent standard of living." 7 In recent years the concept of "human development" has been applied to research on migration and has shown its value in highlighting both positive and negative effects of migration on human development. $^{8}$

So, let us now look at the situation of international migration in Mongolia, and the human security and human development issues it raises.

\section{International Migration in Mongolia}

As noted above, Mongolia has a very small population compared to its neighboring countries (Russia: 144.3 million; China: 1,378.0 million; North Korea: 25.1 million; South Korea: 50.8 million; and Japan: 125.3 million). With a birth rate of 27 per 1,000 persons and a death rate of 6 per 1,000 persons, Mongolia's population growth is naturally small. If the nation needed a faster population growth than the natural growth would allow, it would need to increase immigration (in-migration) and limit emigration (out-migration). However, Mongolia's net migration (immigration minus emigration) is near zero. As a result, its population is forecast to grow from 3.1 million persons in mid-2016 to 3.8 million in mid-2030 and 4.6 million in mid-2050. ${ }^{9}$ Therefore, Mongolia will no doubt remain a small element of global migration.

United Nations Development Programme, "Human Development Reports - Data, Human Development Index." Available from http:/hdr.undp.org/en/content/human-developmentindex-hdi (accessed June 15, 2017).

8 The most comprehensive examination of migration from the human development perspective to date is seen in United Nations Development Program, Human Development Report 2009, Overcoming Barriers: Human Mobility and Development, New York: United Nations Development Programme, 2009. Available from http:/hdr.undp.org/sites/default/files/ reports/269/hdr 2009 en complete.pdf (accessed June 15, 2017).

9 These statistics are from UN Population Reference Bureau. 
From the perspective of international migration, Mongolia's small population has both positive and negative implications. On the positive side are limited emigration and immigration pressure, low administrative costs for handling emigration and immigration applications, little need to adjust its migration policy, low levels of illegal activities accompanying emigration and immigration (e.g., human, drug, and arms trafficking, and migrant smuggling), low law enforcement costs, low costs of social provisions to support foreign immigrants, and limited cultural frictions and misunderstandings. On the negative side, Mongolia receives very little of the benefits generally associated with international migration, e.g., employment, educational, and professional development opportunities - human development opportunities - abroad for Mongolian citizens, remittances to be sent home, national and local tax revenues from Mongolian workers abroad and migrant labor in Mongolia, and entrepreneurial activities of immigrants in the country.

\section{The Migrant populations (migrant stocks)}

Table 1 shows the migrant population and its proportion (\%) of the total population in Mongolia and comparable figures for the other Northeast Asian countries/areas.

Table 1. International migrant stock at midyear and as a proportion of total population in Mongolia and other Northeast Asian countries/areas

\begin{tabular}{|l|r|r|r|r|r|r|}
\hline \multirow{2}{*}{$\begin{array}{l}\text { Country/ area of } \\
\text { destination }\end{array}$} & \multicolumn{6}{|c|}{ International migrant stock at mid-year and as \%o of total } \\
& \multicolumn{7}{|c|}{ population } \\
\cline { 2 - 8 } & \multicolumn{1}{|c|}{$\mathbf{1 9 9 0}$} & \multicolumn{1}{c|}{$\%$} & \multicolumn{1}{c|}{$\mathbf{1 9 9 5}$} & \multicolumn{1}{c|}{$\%$} \\
\hline China & 376361 & 0.0 & 442198 & 0.0 & 508034 & 0.0 \\
\hline Hong Kong SAR & 2218473 & 38.3 & 2443798 & 39.8 & 2669122 & 39.3 \\
\hline Macao SAR & 205047 & 57.0 & 224929 & 56.4 & 240791 & 55.8 \\
\hline North Korea & 34103 & 0.2 & 35143 & 0.2 & 36183 & 0.2 \\
\hline South Korea & 43017 & 0.1 & 123886 & 0.3 & 244178 & 0.5 \\
\hline Japan & 1075626 & 0.9 & 1381097 & 1.1 & 1686567 & 1.3 \\
\hline Mongolia & $\mathbf{6 7 1 8}$ & $\mathbf{0 . 3}$ & $\mathbf{7 4 2 4}$ & $\mathbf{0 . 3}$ & $\mathbf{8 ~ 2 0 6}$ & $\mathbf{0 . 3}$ \\
\hline Russia & 11524948 & 7.8 & 11928927 & 8.0 & 11900297 & 8.1 \\
\hline
\end{tabular}




\begin{tabular}{|l|r|r|r|r|r|r|}
\hline \multirow{2}{*}{$\begin{array}{l}\text { Country/ area of } \\
\text { destination }\end{array}$} & \multicolumn{6}{|c|}{ International migrant stock at mid-year and as \% of total } \\
& \multicolumn{1}{|c|}{ population } \\
\cline { 2 - 8 } & \multicolumn{1}{|c|}{$\mathbf{2 0 0 5}$} & \multicolumn{1}{c|}{$\mathbf{2 0 1 0}$} & \multicolumn{1}{c|}{$\%$} \\
\hline China & 678947 & 0.1 & 849861 & 0.1 & 978046 & 0.1 \\
\hline Hong Kong SAR & 2721235 & 39.8 & 2779950 & 39.8 & 2838665 & 38.9 \\
\hline Macao SAR & 279308 & 59.7 & 318506 & 59.6 & 342703 & 58.3 \\
\hline North Korea & 40097 & 0.2 & 44010 & 0.2 & 48458 & 0.2 \\
\hline South Korea & 485546 & 1.0 & 919275 & 1.9 & 1327324 & 2.6 \\
\hline Japan & 2012916 & 1.6 & 2134151 & 1.7 & 2043877 & 1.6 \\
\hline Mongolia & $\mathbf{1 1 4 7 5}$ & $\mathbf{0 . 5}$ & $\mathbf{1 6 0 6 1}$ & $\mathbf{0 . 6}$ & $\mathbf{1 7 6 2 0}$ & $\mathbf{0 . 6}$ \\
\hline Russia & 11667588 & 8.1 & 11194710 & 7.8 & 11643276 & 8.1 \\
\hline
\end{tabular}

Note: Taiwan is not included in the table because the UN source indicated below does not include statistics on Taiwan, a non-UN member.

Source: Compiled from data in United Nations, Department of Economic and Social Affairs, Trends in International Migrant Stock, The 2015 revision, United Nations database, POP/DB/MIG/STOCK/REV.2015. Available from: http:// www.un.org/en/development/desa/population/migration/data/estimates2/ estimates15.shtml (accessed December 15, 2016).

As Table 1 shows, the international migrant population (stock) in Mongolia in 2015 was 17,620 persons, a $162 \%$ increase from 1990 , but still a small proportion $(0.6 \%)$ of the country's total population. During the same period, North Korea's international migrant population changed very little $(142 \%)$, from 34,103 persons in 1990 to 48,458 persons in 2015 , accounting for only 0.2 percent of the country's population in 2015. The international migrant population in China grew nearly 160 percent, from 376,361 persons in 1990 to 978,046 persons in 2015 , but because of its huge population it represented only 0.1 percent of the country's population in 2015. International migrants represented a far larger part of the population of Russia (8.1\%) in 2015. Among Mongolia's neighboring countries, South Korea experienced the largest growth in the size of international migrant population, from 43,017 persons $(0.1 \%$ of total population) in 1990 to $1,327,324$ persons (2.6\%), a nearly 30 -fold increase. This was largely due to the country's spectacular economic growth during this period.

Rapid increases in foreign populations represent a recent phenomenon in Northeast Asian countries, which have historically adopted restrictive immigration policies, with the two special administration regions of China 
being notable exceptions as they have been heavily populated by expats from Europe along with the mostly Chinese native residents. Dramatic increases in international migration seen in the region generally, as we will discuss later, pose both significant human security challenges and human development opportunities for the Northeast Asian countries, small and large. Mongolia and North Korea, despite their restrictive immigration policies, face their own challenges.

According to the Mongolia Immigration Agency, "as of June 2016 there were more than 42,000 migrants from 128 countries residing in Mongolia regularly. Migrant workers come mainly from China, the Democratic People's Republic of Korea, Russia and Central Asian countries." 10 Conversely, a growing number of Mongolian citizens are finding employment, education, professional development, family reunification, and international marriage opportunities abroad. According to the International Organization for Migration, "international migration has significantly increased with an estimated one in eleven Mongolians living abroad... International migration and mobility of Mongolians is growing exponentially with approximately 65 per cent of Mongolians migrating for economic reasons" (as of 2010). Further, "It is estimated that 130,000 Mongolian migrants are living abroad in 2016, with many in an irregular situation. Normally Mongolian migrants to foreign countries are young people educated and skilled who are in search of higher paid jobs and a better quality of life for themselves and their families. These migrants are mainly males and traveling to other Asian countries (with the majority to China, Russia, Republic of Korea and Japan) some countries in Europe (i.e., Belgium, Czech Republic, Netherlands, Norway, Sweden and Switzerland) and the United States."11

\section{$\underline{\text { Refugees }}$}

Table 2 is constructed from the provisional data in the 2016 midyear report of the United Nations High Commissioner for Refugees (UNHCR) on the number of refugees, people in refugee-like situations, and asylum seekers in Mongolia and other Northeast Asian countries. It is apparent that Mongolia is not a popular destination for asylum-seekers, with only 14 persons granted refugee status and one pending asylum case. In comparison, China and Russia had granted refugees status to well over 300,000, with 654 and 2,088 pending cases of asylum seekers. If Russia or China should deny entry to the large

\footnotetext{
10 International Organization for Migration, "Mongolia," ttps://www.iom.int/countries/mongolia (accessed June 15, 2017).

11 Ibid.
} 
number of asylum seekers who enter their countries, many of them might be forced to go to Mongolia, the closest country in the region. They may seek asylum there or transit the country for another country where they seek refuge. Among such populations are North Korean defectors who cross North KoreanChinese border to flee political persecution, economic hardships, or other serious human security problems in their home country.

Table 2. Refugees and asylum seekers by country/territory of asylum, mid-2016

\begin{tabular}{|l|r|r|r|}
\hline $\begin{array}{c}\text { Country of asylum or } \\
\text { residence }\end{array}$ & Refugees & \multicolumn{1}{c|}{$\begin{array}{c}\text { Of whom assisted } \\
\text { by UNHCR }\end{array}$} & $\begin{array}{c}\text { Asylum-seekers } \\
\text { (pending cases) }\end{array}$ \\
\hline China & 301,043 & 148 & 654 \\
\hline South Korea & 1,532 & 163 & 6,295 \\
\hline Japan & 2,462 & 372 & 16,324 \\
\hline Mongolia & $\mathbf{1 4}$ & $\mathbf{1 4}$ & $\mathbf{1}$ \\
\hline Russia & 314,507 & 7,071 & 2,088 \\
\hline
\end{tabular}

Notes: Data for North Korea are not available. Data are provided by each government according to its own definition and method of data collection.

Source: Constructed with data from UNHCR, Mid-year Trends, 2016, New York: UNHCR, 2016, pp. 28-30. Downloadable from http://www.unhcr.org/en-us/ statistics/unhcrstats/58aa8f247/mid-year-trends-june-2016.html (accessed June 17, 2017)

The picture changes dramatically when we look at the number of refugees and asylum-seekers by origin. Table 3 shows those numbers. China features most prominently as the country of origin for 212,357 refugees at mid-year 2016, with another 64,057 asylum seekers from the country whose cases were pending. Russian-origin asylum-seekers were not nearly as numerous but still significant, with 64,691 refugees and 29,005 pending asylum cases. Mongolia was the third largest country of origin for both refugees and asylum-seekers, with 2,246 persons in the first category and 3,584 in the second category. North Korea was the origin of 1,081 refugees and 453 asylum-seekers whose cases were pending as of mid-year 2016. 
Table 3. Refugees and asylum seekers by country/territory of origin, mid-2016

\begin{tabular}{|l|r|r|r|}
\hline Country of origin & \multicolumn{1}{|c|}{ Refugees } & $\begin{array}{c}\text { Of whom assisted } \\
\text { by UNHCR }\end{array}$ & $\begin{array}{c}\text { Asylum-seekers } \\
\text { (pending cases) }\end{array}$ \\
\hline China & 212,357 & 250 & 64,057 \\
\hline North Korea & 1,081 & 74 & 453 \\
\hline South Korea & 338 & & 265 \\
\hline Japan & 87 & -- & 69 \\
\hline Mongolia & $\mathbf{2 , 2 4 6}$ & -- & $\mathbf{3 , 5 8 4}$ \\
\hline Russia & 64,691 & 902 & 29,005 \\
\hline
\end{tabular}

Source: Constructed with data from UNHCR, Mid-year Trends, 2016, New York: UNHCR, 2016, pp. 28-30. Downloadable from http://www.unhcr.org/en-us/ statistics/unhcrstats/58aa8f247/mid-year-trends-june-2016.html (accessed June 17, 2017)

\section{Human trafficking}

Human trafficking involving Mongolia occurs across its national borders and also within the country. "Mongolian girls and young women are the main victims of human trafficking, mainly for sexual exploitation or commercially brokered marriages, but there are cases of men and women subjected to forced labor." 12 The United States State Department's Trafficking in Persons Report 2016 ("TIP Report" hereafter) rates Mongolia as a Tier 2 country, meaning the Mongolian government does not fully meet the minimum standards set by the U.S. anti-trafficking legislation (Trafficking Victims Protection Act) but is undertaking significant efforts to meet those standards. ${ }^{13}$ The Report states, "Mongolia is a source and, to a lesser extent, a destination country for men, women, and children subjected to forced labor and sex trafficking. Mongolian men, women, and children are subjected to forced labor in Turkey, Kazakhstan, and Israel and to sex trafficking in South Korea, Japan, China, Hong Kong, Malaysia, Germany, Sweden, and the United States," and "Women are subjected to domestic servitude or forced prostitution after entering into commercially brokered marriages to Chinese men and, with decreased frequency, South

\footnotetext{
12 International Organization for Migration, "Mongolia."

13 Trafficking in Persons Report, June 2016, Washington, D.C.: United States Department of State, 2016, p. 316. Available from https://www.state.gov/documents/organization/258876.pdf (accessed June 15, 2017).
} 
Korean men."14

The TIP Report also states, "North Korean and Chinese workers employed in Mongolia are vulnerable to trafficking as contract laborers in construction, production, agriculture, forestry, fishing, hunting, wholesale and retail trade, automobile maintenance, and mining." The TIP Report further notes that "North Korean laborers do not have freedom of movement or choice of employment and are allowed to keep only a small portion of their wages while being subjected to harsh working and living conditions. Chinese workers have reported non-payment of wages." 15

\section{The human security and development challenges to foreign migrants in Mongolia}

The human security - freedom from fear, freedom from want, and freedom from indignities - of international migrants in Mongolia, as elsewhere in the Northeast Asia region, is at risk. According to the International Organization for Migration, immigration to Mongolia and emigration from Mongolia present various challenges, including "unsafe migration, fraud, border inspection avoidance, visa violations and an increased incidence of human trafficking." 16 An IOM report on Mongolia notes, "Due to the remoteness of the country's vast international borders and challenges faced by its border and identity management systems, fraud, border inspection avoidance and visa violations are significant challenges for the Government of Mongolia and contribute to similar problems in neighboring countries." 17 The Mongolian government has shown interest in protecting migrants' human rights, including in combating human trafficking and increasing the positive impact of migration as part of the national development agenda. ${ }^{18}$ That is, the government is apparently concerned about some of the human security and human development aspects of international migration.

The rights of migrant workers, asylum-seekers and refugees, victims of human trafficking, and smuggled migrants are enshrined in various international conventions. Relevant conventions and their supplementary protocols include: 1951 International Convention relating to the Status of Refugees (Refugee Convention); 1967 Protocol relating to the Status of Refugees

\footnotetext{
Ibid.

15 Ibid.

16 International Organization for Migration, "Mongolia."

17 Ibid.

18 Ibid.
} 
(Refugee Protocol); International Convention on the Protection of the Rights of All Migrant Workers and Members of Their Families (Migrant Workers Convention); UN Convention against Transnational Organized Crime; Protocol to Prevent, Suppress and Punish Trafficking in Persons, Especially Women and Children, supplementing the United Nations Convention against Transnational Organized Crime (Human Trafficking Protocol); Protocol against the Smuggling of Migrants by Land, Sea and Air, supplementing the United Nations Convention against Transnational Organized Crime (Migrant Smuggling Protocol); ILO Convention concerning Migrations in Abusive Conditions (C097); and the Promotion of Equality of Opportunity and Treatment of Migrant Workers (C143).

Table 4 shows the status of ratifications by the Northeast Asian countries of these treaties.

Table 4. Status of ratifications by Northeast Asian countries of principal international conventions concerning migrants, refugees, and human trafficking and migrant smuggling

\begin{tabular}{|l|c|c|c|c|}
\hline $\begin{array}{c}\text { Convention } \\
\text { Country }\end{array}$ & CMW & RC & RP & CTOC \\
\hline China & No action & Acceded & Acceded & Ratified \\
\hline Japan & No action & Acceded & Acceded & Signatory \\
\hline North Korea & No action & No action & No action & Acceded \\
\hline South Korea & No action & Acceded & Acceded & Ratified \\
\hline Mongolia & No action & No action & No action & Acceded \\
\hline Russia & No action & Acceded & Acceded & Ratified \\
\hline
\end{tabular}

\begin{tabular}{|l|c|c|c|c|}
\hline $\begin{array}{c}\text { Convention } \\
\text { Country }\end{array}$ & TIPP & MSP & ILO C097 & ILO C143 \\
\hline China & No action & No action & No action & No action \\
\hline Japan & Signatory & Signatory & No action & No action \\
\hline North Korea & No action & No action & No action & No action \\
\hline South Korea & Ratified & Ratified & No action & No action \\
\hline Mongolia & Acceded & Acceded & No action & No action \\
\hline Russia & Ratified & Ratified & No action & No action \\
\hline
\end{tabular}

Notes: Taiwan is not included in the table as it is not a member of the United Nations.

CMW: International Convention on the Protection of the Rights of All Migrant Workers and Members of Their Families

RC: 1951 Refugee Convention

RP: 1967 Protocol relating to the Status of Refugees

CTOC: UN Convention against Transnational Organized Crime

TIPP: Protocol to Prevent, Suppress and Punish Trafficking in Persons, 
Especially Women and Children, supplementing the United Nations Convention against Transnational Organized Crime

MSP: Protocol against the Smuggling of Migrants by Land, Sea and Air, supplementing the United Nations Convention against Transnational Organized Crime

ILO C097: ILO Convention concerning Migration for Employment (Revised 1949)

ILO C143: ILO Convention concerning Migrations in Abusive Conditions and the Promotion of Equality of Opportunity and Treatment of Migrant Workers

"Acceded": The state has expressed its consent by acceding to the treaty and where the treaty has entered into force.

"Ratified": The state has expressed its consent by ratifying the treaty and where the treaty has entered into force.

"Signatory": The state provided a preliminary endorsement of the instrument and its intent to examine the treaty domestically and consider ratifying the instrument.

"No action": The state did not express its consent

Sources: United Nations Human Rights Office of the High Commissioner, "Status of Ratification Interactive Dashboard," http://indicators.ohchr. org (accessed June 15, 2017); United Nations High Commissioner for Refugees, "States Parties to the 1951 Convention relating to the Status of Refugees and the 1967 Protocol," http://www.unhcr.org/en-us/protection/ basic/3b73b0d63/states-parties-1951-convention-its-1967-protocol. $\underline{\mathrm{html}}$ (accessed June 16, 2017); United Nations "Treaty Collection," https://treaties.un.org/pages/ViewDetails.aspx?src=TREATY\&mtdsg

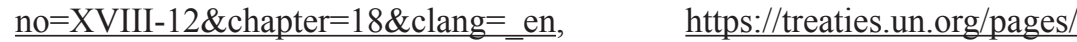
viewdetails.aspx? $\mathrm{src}=$ ind $\&$ mtdsg no $=$ xviii-12-a\&chapter $=18$, and https:// treaties.un.org/pages/viewdetails.aspx? src=ind\&mtdsg no=xviii-12b\&chapter=18\&lang=en (accessed June 16, 2017); International Labor Organization, " Ratifications of C097 - Migration for Employment Convention (Revised), 1949 (No. 97),” http://www.ilo.org/dyn/normlex/ en/f?p=1000:11300:0::NO:11300:P11300_INSTRUMENT_ID:312242 (accessed June 16, 2017); and International Labor Organization, "Ratifications of C143 - Migrant Workers (Supplementary Provisions) Convention, 1975 (No. 143), http://www.ilo.org/dyn/normlex/en/f?p=1000 :11300:0::NO:11300:P11300 INSTRUMENT ID:312288 (accessed June 16, 2017). 


\section{$\underline{\text { Labor migration }}$}

Labor migrants, including documented (legal) and undocumented (illegal) workers, are subjected to a myriad of rights abuses. Undocumented workers include those who have been smuggled into Mongolia, often with the aid of recruiters in their home countries and other intermediaries. Among the problems that both documented and undocumented migrant workers face in Mongolia, as elsewhere in the region, are excessively long work hours, lack of healthcare, unpaid wages, delayed payment of wages, weak or nonexistent safety protections, substantial debts to recruiting agents, difficulty or impossibility of changing jobs, and lack of readily available legal and other assistance.

The International Convention on the Protection of the Rights of All Migrant Workers and Members of Their Families (Migrant Workers Convention) was adopted by the UN General Assembly in December 1990. It is by far the most comprehensive international legal instrument promoting the rights of migrants. It enables all those persons who qualify as migrant workers under its provisions, to enjoy their human rights regardless of their legal status. Article 2 paragraph 1 defines "migrant worker" as "a person who is to be engaged, is engaged or has been engaged in a remunerated activity in a State of which he or she is not a national." "Migrant workers" include: "frontier worker"; "seasonal worker"; "seafarer"; "worker on an offshore installation"; "itinerant worker"; "projecttied worker"; "specified-employment worker"; and "self-employed worker."

The Convention protects both documented and undocumented workers by setting human rights standards that individual States must guarantee. When a State ratifies or accedes to the Convention, it is required to undertake to adopt the legislative and other measures that are necessary to implement the provisions of the Convention. States also undertake to ensure that migrants whose rights have been violated may seek judicial remedy. These requirements are apparently too overwhelming for the Northeast Asian countries to meet; hence, none of the countries have consented to the Convention.

\section{Refugees}

The cornerstone of the 1951 Convention relating to the Status of Refugees is the principle of non-refoulement, which provides:

A refugee should not be returned to a country where he or she faces serious threats to his or her life or freedom. This protection may not be claimed by refugees who are reasonably regarded as a danger to the security of the country, or having been convicted of a particularly serious crime, are considered a danger to the community (Article 33). 
Other rights contained in the 1951 Convention include: The right not to be expelled, except under certain, strictly defined conditions (Article 32); the right not to be punished for illegal entry into the territory of a contracting State (Article 31); the right to work (Articles 17 to 19); the right to housing (Article 21); the right to education (Article 22); the right to public relief and assistance (Article 23); the right to freedom of religion (Article 4); the right to access the courts (Article 16); the right to freedom of movement within the territory (Article 26); and the right to be issued identity and travel documents (Articles 27 and 28). Further, the convention provides that refugees are required to abide by the laws and regulations of their country of asylum and respect measures taken for the maintenance of public order.

Mongolia and North Korea have not consented to either the 1951 Refugee Convention or the 1967 Protocol, which removed the geographical and time limits of the 1951 Convention. These limits initially restricted the Convention to persons who became refugees due to events occurring in Europe before 1 January 1951. All other Northeast Asian countries have acceded to both the 1951 convention and the 1967 protocol. This is obviously problematic because, as noted above, there are huge numbers of refugees within the region but none of them can expect legal protection while in Mongolia or North Korea. Another problem is that even though China has acceded to both the 1951 convention and the 1967 protocol, China does not offer protection to the North Koreans who have fled their country (commonly known as "North Korean defectors") and entered Chinese territory. Far from it, the Chinese government generally does not recognize them as refugees and instead labels them as illegal "economic migrants" and, in accordance with a bilateral treaty it has with North Korea, forcibly returns them to North Korea, to face harsh punishment. ${ }^{19}$

If Mongolia ratifies the 1951 Refugee Convention, the refugees in the country and the Mongolian refugees in other countries will be entitled to the legal protections enshrined in the convention.

\section{Human trafficking}

The Protocol to Prevent, Suppress and Punish Trafficking in Persons, Especially Women and Children, supplementing the United Nations Convention against Transnational Organized Crime was adopted by General Assembly resolution 55/25, to supplement the UN Convention and entered into force on December 25, 2003. Article 3 subparagraph (a) defines "trafficking in persons"

19 See, for example, "North Korea: Events of 2015," in Human Rights Watch's World Report 2016. Available from https://www.hrw.org/world-report/2016/country-chapters/north-korea (accessed June 15, 2017). 
as:

"The recruitment, transportation, transfer, harboring or receipt of persons, by means of the threat or use of force or other forms of coercion, of abduction, of fraud, of deception, of the abuse of power or of a position of vulnerability or of the giving or receiving of payments or benefits to achieve the consent of a person having control over another person, for the purpose of exploitation. Exploitation shall include, at a minimum, the exploitation of the prostitution of others or other forms of sexual exploitation, forced labor or services, slavery or practices similar to slavery, servitude or the removal of organs."

Article 3 subparagraph (b) provides: "The consent of a victim of trafficking in persons to the intended exploitation...shall be irrelevant where any of the means set forth in subparagraph (a) have been used." Article 3 subparagraph (c) states: "The recruitment, transportation, transfer, harboring or receipt of a child for the purpose of exploitation shall be considered "trafficking in persons" even if this does not involve any of the means set forth in subparagraph (a) of this article." Further, subparagraph (d) defines "child" as "any person under eighteen years of age." Other provisions of the Protocol relates to criminalization, assistance to and protection for victims, the status of victims in the receiving states, repatriation of victims, preventive measures, actions to discourage the demand, exchange of information and training, and measures to strengthen the effectiveness of border controls. Further, the Protocol stipulates that states parties must adopt or strengthen legislative or other measures to discourage the demand that fosters all forms of exploitation of persons, especially women and children that leads to trafficking.

Trafficking victims in Mongolia come from within Northeast Asia as well as from outside of the region. They include men, women, and children of myriad nationalities. Forced labor and forced prostitution obviously constitute an outright violation of the victims' human rights. Although many Mongolian nationals are also trapped into these horrible situations, including when they go abroad, foreign victims in Mongolia are very vulnerable because of their legal status (or lack thereof). Traffickers often do not allow them to carry a passport; even if they have a passport employers often confiscate it to prevent them from reporting their situation to local authorities; and many victims choose not to report for fear of bodily harm, not only to themselves but also to their family members back home. These problems typically take place outside of the monitoring capacity of national governments. We noted the human trafficking problem in Mongolia in the preceding section. The IOM report quoted above states, "The incidence of human trafficking is still significant in Mongolia, particularly of young women and girls who are sexually exploited 
for commercial gain. The main destination country is the People's Republic of China, including Macau and Hong Kong Special Autonomous Regions." ${ }^{20}$

The 2016 TIP Report of the U.S. Department of State recommends that Mongolia establish "formal procedures to guide government officials in victim identification and referral to protective services; cease penalizing trafficking victims for offenses committed as a result of being subjected to trafficking; allocate funding to support both government- and NGO-run shelters and other forms of victim assistance and protection; monitor working conditions and investigate claims of labor exploitation of foreign contractors employed in Mongolia; enact the remaining regulation needed to fully implement the 2012-anti-trafficking law and train officials on effective implementation; increase efforts to investigate and prosecute all trafficking offenses using article 113 of the criminal code; implement the national action plans to combat trafficking and protect victims; and reduce the demand for commercial sex acts, particularly throughout major transportation hubs."21

\section{Migrant smuggling}

The Protocol against the Smuggling of Migrants by Land, Sea and Air, supplementing the United Nations Convention against Transnational Organized Crime was adopted by General Assembly resolution 55/25, and entered into force on January 28, 2004. Article 3 subparagraph (a) defines "smuggling of migrants" as "the procurement, in order to obtain, directly or indirectly, a financial or other material benefit, of the illegal entry of a person into a State Party of which the person is not a national or a permanent resident." Article 3 subparagraph (b) defines "illegal entry" as "crossing borders without complying with the necessary requirements for legal entry into the receiving State." The Protocol aims at preventing and combating the smuggling of migrants, as well as promoting cooperation among States parties, while protecting the rights of smuggled migrants and preventing the worst forms of their exploitation which often characterize the smuggling process.

As Table 4 shows, China and North Korea have not consented to either the Human Trafficking Protocol or the Migrant Smuggling Protocol. Japan has signed both protocols but has not ratified either. All other Northeast Asian countries, including Mongolia, have consented to both protocols by either ratifying or acceding to them. With this uneven status among the regional countries, cooperation among them is difficult, with different sets of legal rules being applicable to different countries.

\footnotetext{
20 Ibid.

${ }^{21}$ Trafficking in Persons Report, June 2016, p. 273.
} 
Studies of migrant smuggling into and out of Mongolia are virtually nonexistent and statistical and other data on migrant smuggling in the country are equally scarce. ${ }^{22}$ For the Northeast Asia region as a whole, a 2016 IOM report states, "The biggest source countries are China and North Korea, followed by a smaller source from Mongolia and the Russian Federation. The destination countries are South Korea and Japan." ${ }^{23}$ As Table 3 shows, Mongolia has acceded to the Protocol against the Smuggling of Migrants by Land, Sea and Air, supplementing the United Nations Convention against Transnational Organized Crime. ${ }^{24} \mathrm{By}$ far the largest population of smuggled migrants is the Chinese, with Canada and the Philippines being the largest destinations according to the UN Office of Drugs and Crime (UNODC). ${ }^{25}$ Mongolia does not appear on the UNODC list, indicating that statistics are not available and/or the number of Mongolian smuggled out of the country is very small. The people who are smuggled into Mongolia who are significant from the perspective of human security are North Korean defectors. Very little is known about them. Even though their number is likely very small, they are nonetheless significant because Mongolia's neighbor China forcibly repatriates North Korean defectors who enter their territory and whom they define as "illegal migrants" rather than "refugees." As well, very little is known about North Korean defectors who end up in Russia.

In summary, Mongolia has fallen behind some of its neighboring countries in accepting the legal rules and principles established by the 1951 Refugee Convention, and the 1967 Refugee Protocol. It is important to note that a country whose citizens are subjected to mistreatment, discrimination, and other forms of rights abuse while in a foreign country, the first country has a stronger case to press against the second country if both countries have accepted the legal rules and principles found in treaties mentioned above. Moreover, according to the principle of reciprocity under international law, the first country can demand that its citizens who are in the territory under the second country's jurisdiction be accorded the same treatment as the citizens of the second country who are in the territory to whom the first country accords the rights protections under international law. So, it matters that not only Mongolia but also the other countries where Mongolian citizens may find themselves have consented to the international treaties pertaining to border-crossing individuals, including the UN

\footnotetext{
22 Jiyoung Song, "Northeast Asia," in M.L. McAuliffe and F. Laczko, eds., Migrant Smuggling Data and Research: A Global Review of the Emerging Evidence Base, Geneva: International Organization for Migration, 2016, p. 251 and p. 253.

23 Ibid., p. 243.

24 United Nations Office on Drugs and Crime, "Signatories to the United Nations Convention against Transnational Crime and its Protocols." Available from www.unodc.org/unodc/en/ treaties/CTOC/signatures.html (accessed on June 16, 2017).

25 Cited in Jiyoung Song, "Northeast Asia," p. 245.
} 
Convention against Transnational Organized Crime and its two protocols, on human trafficking and migrant smuggling. With respect to the Migrant Workers Convention and the two ILO conventions related to migrant workers, none of the Northeast Asian countries have consented to them. From the perspective of the human security and human development of migrant workers, every Northeast Asian country should aspire to meet the rules and standards envisaged by the conventions.

\section{Mongolia and universal human rights conventions}

Of even more fundamental importance is the compliance of Mongolia and other countries with the legal rules and principles established by universal human rights conventions and other principal human rights treaties. Such rules and principles apply to all persons regardless of their citizenship, country of origin, current location, gender, age, or immigration-related status. Table 5 shows the status of ratifications by Mongolia and other Northeast Asian countries of the principal international human rights conventions. It is encouraging that Mongolia has consented to all the relevant conventions.

Table 5. Status of ratifications by Northeast Asian countries of principal international human rights conventions

\begin{tabular}{|l|l|l|l|l|l|}
\hline $\begin{array}{c}\text { Convention } \\
\text { Country }\end{array}$ & ICESCR & \multicolumn{1}{|c|}{ ICCPR } & ICERD & CEDAW & CRC \\
\hline China & State party & Signatory & State party & State party & State party \\
\hline Japan & State party & State party & State party & No action & State party \\
\hline North Korea & State party & State party & No action & State party & State party \\
\hline South Korea & State party & State party & State party & State party & State party \\
\hline Mongolia & State party & State party & State party & State party & State party \\
\hline Russia & State party & State party & State party & State party & State party \\
\hline
\end{tabular}

Notes: Taiwan is not included in the table as it is not a member of the United Nations.

ICESCR: International Covenant on Economic, Social and Cultural Rights ICCPR: International Covenant on Civil and Political Rights

ICERD: International Convention on the Elimination of All Forms of Racial Discrimination

CEDAW: Convention on the Elimination of All Forms of Discrimination against Women 
CRC: Convention on the Rights of the Child

"State party": The state has expressed its consent, by an act of ratification, accession or succession, and where the treaty has entered into force (or a State about to become a party after formal reception by the United Nations Secretariat of the State's decision to be a party).

"Signatory": The state provided a preliminary endorsement of the instrument and its intent to examine the treaty domestically and consider ratifying it.

"No action": The state did not express its consent.

Source: United Nations Human Rights Office of the High Commissioner, "Status of Ratification Interactive Dashboard," http://indicators.ohchr.org (accessed June 15, 2017)

Mongolia and all other Northeast Asian countries are bound by the International Covenant on Economic, Social, and Cultural Rights (ICESCR), the International Covenant on Civil and Political Rights (ICCPR), the International Convention on the Elimination of All Forms of Racial Discrimination (ICERD), the Convention on the Elimination of All Forms of Discrimination against Women (CEDAW), and the Convention on the Rights of the Child (CRC). The only exceptions are Japan, which has not consented to CEDAW, and North Korea, which has not embraced ICERD. Mongolian citizens who are in these two countries are at the mercy of Japanese and North Korean domestic law and practice when it comes to the protection of raceor gender-based human rights. It is important, however, that Mongolia has accepted all universal human rights treaties because by according Japanese and North Korean citizens within Mongolia the protections enshrined in those treaties the Mongolian government is in a strong position to make moral appeals to Japan and North Korea about the treatment of its citizens in these countries and, if necessary, to take cases of discrimination against its citizens in those countries to international human rights courts.

More generally, beyond the legal protections or moral arguments that apply to the rights of Mongolian citizens abroad or foreign nationals within Mongolia, there are political, economic, and social conditions in Mongolia that affect the actual human security condition of both citizens and non-citizens in the country. In other words, "human security" goes beyond the legally defined or morally advocated "rights." As such, we need to address those other elements of human security in Mongolia, even though we recognize that they may not affect foreign nationals in Mongolia in the same manner or to the same degree as they affect Mongolian citizens in the country. In the remainder of this section, therefore, we will draw on the concept of "human security" and "human development" in discussing those other elements. 
Generally speaking, international migrants face varying degrees of challenges in pursuing their human development depending on where they are located and what opportunities the host countries offer to non-citizens, including international migrants. Fundamental to the challenges they face in the host country is their limited or nonexistent ability to participate in political or community life. As "outsiders," they generally do not have guaranteed access to opportunities to seek long and healthy life, knowledge, and decent standard of living; they are left to their own devices for their own human development. It is safe to assume that opportunities for international migrants are generally more limited than those for the citizens of the host countries.

\section{Mongolia and human security and human development}

In 1990 the United Nations Development Programme released its first Human Development Report and introduced the concept of "human development." According to the UNDP, human development is about "expanding the richness of human life, rather than simply the richness of the economy in which human beings live." "26 "Human development" has three main components, long and healthy life, knowledge, and decent standard of living, and necessary conditions for it include: participation in political and community life; environmental sustainability; human security and rights; and promotion of equality and social justice. ${ }^{27}$ That is, "human development" understood in this way is inclusive of "human security."

The most recent Human Development Report by UNDP, released in $2016,{ }^{28}$ ranks 188 countries in terms of their standing in 2015 in terms of Human Development Index (HDI), excluding countries and territories for which data availability is too limited to include them in the ranking. HDI is a composite index comprising three basic dimensions: Life expectancy at birth; mean years of schooling; and gross national income per capita. According to the 2016 report, "Life expectancy reflects the ability to lead a long and healthy life. Mean years of schooling and expected years of schooling reflect the ability to acquire knowledge. And gross national income per capita reflects the ability to achieve a decent standard of living." ${ }^{29}$ Table 6 shows Mongolia and the other Northeast Asian countries and their ranking, except for the unranked North Korea for

\footnotetext{
26 UNDP, "Human Development Reports: About Human Development." Available from http:// hdr.undp.org/en/humandev (accessed June 16, 2017).

27 Ibid.

28 United Nations Development Programme, Human Development Report 2016: Human Development for Everyone, New York: UNDP, 2016.

29 Ibid., p. 3.
} 
which data are incomplete.

Table 6. Human development and its components in Northeast Asian countries, 2015

\begin{tabular}{|c|l|r|r|r|r|r|}
\hline $\begin{array}{c}\text { HDI } \\
\text { rank }\end{array}$ & Country & $\begin{array}{c}\text { Human } \\
\text { Development } \\
\text { Index (HDI) }\end{array}$ & $\begin{array}{c}\text { Life } \\
\text { expectancy } \\
\text { at birth }\end{array}$ & $\begin{array}{c}\text { Expected } \\
\text { years of } \\
\text { schooling }\end{array}$ & $\begin{array}{c}\text { Mean } \\
\text { years of } \\
\text { schooling }\end{array}$ & $\begin{array}{c}\text { Gross national } \\
\text { income (GNI) } \\
\text { per capital }\end{array}$ \\
\hline 17 & Jalue & (years) & (years) & (years) & (2011 PPP \$) \\
\hline 18 & $\begin{array}{l}\text { South } \\
\text { Korea }\end{array}$ & 0.903 & 83.7 & 15.3 & 12.5 & 37,268 \\
\hline 49 & Russia & 0.804 & 82.1 & 16.6 & 12.2 & 34,541 \\
\hline 90 & China & 0.738 & 76.0 & 13.5 & 7.6 & 13,345 \\
\hline $\mathbf{9 2}$ & Mongolia & $\mathbf{0 . 7 3 5}$ & $\mathbf{6 9 . 8}$ & $\mathbf{1 4 . 8}$ & $\mathbf{9 . 8}$ & $\mathbf{1 0 , 4 4 9}$ \\
\hline$*$ & $\begin{array}{l}\text { North } \\
\text { Korea }\end{array}$ &.. & 70.5 & 12.0 &.. &.. \\
\hline
\end{tabular}

Note: $\quad *$ North Korea is not ranked because of incomplete data.

Source: Selected from United Nations Development Programme, Human Development Report 2016: Human Development for Everyone, New York: UNDP, 2016, pp. 198-199, 201.

Japan, South Korea, and Russia, respectively ranked $17^{\text {th }}, 18^{\text {th }}$, and $49^{\text {th }}$, are considered to have achieved "very high human development," while China and Mongolia, respectively in $90^{\text {th }}$ and $92^{\text {nd }}$ place, are categorized as "high human development" countries. We can surmise that international migrants in these countries generally find themselves in those socio-economic conditions that have produced the life expectancy, level of education, and income levels found among the local nationals and others who have lived in Mongolia for extended periods of time. We should quickly add that this is a general statement that needs to be validated by empirical research.

Table 6 shows the trends in HDI between 1990 and 2015. Mongolia's HDI improved over time and the average annual growth rate exceeded that of all other Northeast Asian countries except China. China experienced a sustained improvement in its HDI, with an average annual growth rate of a $1.57 \%$ during this period. 
Table 6. Human Development Index trends, 1990-2015

\begin{tabular}{|c|l|c|c|c|c|c|c|c|c|c|}
\hline & & \multicolumn{7}{|c|}{$\begin{array}{c}\text { Human Development Index (HDI) } \\
\text { Value }\end{array}$} & $\begin{array}{c}\text { Average } \\
\text { annual HID } \\
\text { growth (\%) }\end{array}$ \\
\hline $\begin{array}{l}\text { HDI } \\
\text { rank }\end{array}$ & Country & 1990 & 2000 & 2010 & 2011 & 2012 & 2013 & 2014 & 2015 & $1990-2015$ \\
\hline 17 & Japan & 0.814 & 0.856 & 0.884 & 0.889 & 0.894 & 0.899 & 0.902 & 0.903 & 0.42 \\
\hline 18 & $\begin{array}{l}\text { South } \\
\text { Korea }\end{array}$ & 0.731 & 0.820 & 0.884 & 0.889 & 0.891 & 0.896 & 0.899 & 0.901 & 0.84 \\
\hline 49 & Russia & 0.733 & 0.720 & 0.785 & 0.792 & 0.799 & 0.803 & 0.805 & 0.804 & 0.37 \\
\hline 90 & China & 0.499 & 0.592 & 0.700 & 0.703 & 0.713 & 0.723 & 0.734 & 0.738 & 1.57 \\
\hline $\mathbf{9 2}$ & Mongolia & $\mathbf{0 . 5 7 9}$ & $\mathbf{0 . 5 8 8}$ & $\mathbf{0 . 7 0 1}$ & $\mathbf{0 . 7 1 2}$ & $\mathbf{0 . 7 2 0}$ & $\mathbf{0 . 7 2 9}$ & $\mathbf{0 . 7 3 3}$ & $\mathbf{0 . 7 3 5}$ & $\mathbf{0 . 9 6}$ \\
\hline
\end{tabular}

Note: North Korea is not included because HDI data are missing.

Source: Selected from United Nations Development Programme, Human Development Report 2016: Human Development for Everyone, New York: UNDP, 2016, pp. 202-203, 205.

Table 7 shows how the Northeast Asian countries are doing in terms of several indicators the UNDP deems relevant to the human security condition in each country. The indicators include: birth registration; refugees by country of origin; internally displaced persons; homeless people due to natural disaster; orphaned children; prison population; homicide rate; suicide rate; justification of wife beating; violence against women ever experienced; and depth of food deficit. 
Table 7. Human security in Northeast Asian countries

\begin{tabular}{|c|l|c|c|c|c|c|}
\hline & $\begin{array}{c}\text { Birth } \\
\text { registration }\end{array}$ & $\begin{array}{c}\text { Refugees by } \\
\text { country of } \\
\text { origin }\end{array}$ & $\begin{array}{c}\text { Internally } \\
\text { displaced } \\
\text { persons }\end{array}$ & $\begin{array}{c}\text { Homeless } \\
\text { people due to } \\
\text { natural disaster }\end{array}$ & $\begin{array}{c}\text { Prison } \\
\text { population }\end{array}$ \\
\hline $\begin{array}{c}\text { (\%) under } \\
\text { age 5 }\end{array}$ & (thousands) & (thousands) & $\begin{array}{c}\text { (average } \\
\text { annual per } \\
\text { million people) }\end{array}$ & $\begin{array}{c}\text { (per } \\
100,000 \\
\text { people) }\end{array}$ \\
\hline $\begin{array}{c}\text { HDI } \\
\text { rank }\end{array}$ & Country & $2010-2015$ & 2015 & 2015 & $2005 / 2015$ & $2004-2015$ \\
\hline 17 & Japan & 100 & 0.1 & -- & 29 & 48 \\
\hline 18 & South Korea & -- & 0.4 & -- & 8 & 101 \\
\hline 49 & Russia & 100 & 67.1 & 27.0 & 9 & 445 \\
\hline 90 & China & -- & 212.9 & -- & 203 & 119 \\
\hline $\mathbf{9 2}$ & Mongolia & $\mathbf{9 9}$ & $\mathbf{2 . 2}$ & -- & $\mathbf{0}$ & $\mathbf{2 6 6}$ \\
\hline$*$ & North Korea & 100 & 1.1 & -- & 1,315 & - \\
\hline
\end{tabular}

\begin{tabular}{|c|c|c|c|c|c|c|c|}
\hline & & $\begin{array}{l}\text { Homicide } \\
\text { rate }\end{array}$ & \multicolumn{2}{|c|}{ Suicide rate } & \multicolumn{2}{|c|}{$\begin{array}{c}\text { Justification of } \\
\text { wife beating }\end{array}$} & $\begin{array}{c}\text { Depth of } \\
\text { food deficit }\end{array}$ \\
\hline & & \multirow{2}{*}{$\begin{array}{c}\text { (per } \\
100,000 \\
\text { people) }\end{array}$} & \multicolumn{2}{|c|}{$\begin{array}{c}\text { (per } 100,000 \\
\text { people) }\end{array}$} & \multicolumn{2}{|c|}{$\begin{array}{c}(\% \text { ages } 15- \\
49)\end{array}$} & \multirow{2}{*}{$\begin{array}{c}\text { (kilocalories } \\
\text { per person } \\
\text { per day) }\end{array}$} \\
\hline & & & Female & Male & Female & Male & \\
\hline $\begin{array}{l}\text { HDI } \\
\text { rank }\end{array}$ & Country & $2010-2014$ & 2012 & 2012 & $\begin{array}{l}2010- \\
2015\end{array}$ & $\begin{array}{c}2010- \\
2015\end{array}$ & $2013 / 2015$ \\
\hline 17 & Japan & 0.3 & 10.1 & 26.9 & -- & -- & -- \\
\hline 18 & South Korea & 0.7 & 18.0 & 41.7 & -- & -- & 4 \\
\hline 49 & Russia & 9.5 & 6.2 & 35.1 & -- & -- & -- \\
\hline 90 & China & 0.8 & 8.7 & 7.1 & -- & -- & 78 \\
\hline 92 & Mongolia & 7.5 & 3.7 & 16.3 & 10.0 & 9.0 & 165 \\
\hline$*$ & North Korea & 4.7 & -- & -- & -- & -- & 344 \\
\hline
\end{tabular}

Note: * North Korea is not ranked because of incomplete data.

Source: Selected from United Nations Development Programme, Human Development Report 2016: Human Development for Everyone, New York: UNDP, 2016, pp. 242-243, 245. 
"Refugees" are defined as "people who have fled their country of origin because of a well founded fear of persecution due to their race, religion, nationality, political opinion or membership in a particular social group and who cannot or do not want to return to their country of origin." ${ }^{30}$ The table shows that in 2015 there were 2,200 Mongolian refugees around the world. This is a significant number for a country whose total population is only 3.1 million. According to Table 7, the number of internally displaced persons (IDPs) in Mongolia in 2015 was unknown. The homeless population in the country was virtually zero. In comparison with other Northeast Asian countries, Mongolia's prison population, 266 per 100,000 persons, was relatively large. "Prison population" is defined as "number of adult and juvenile prisoners - including pretrial detainees, unless otherwise noted - expressed per 100,000 people." 31 It is unknown how man of these prisoners were Mongolian nationals and how many were foreign nationals. The homicide rate, which is defied as "number of unlawful deaths purposefully inflicted on a person by another person, expressed per 100,000 people," ${ }^{32}$ was 7.5 per 100,000 persons in Mongolia in 2010-2014, placing the country in a higher range among the Northeast Asian countries, with Russia having the highest rate ( 9.5 per 100,000 persons) and Japan, the lowest rate ( 0.3 per 100,000 persons). Mongolia's suicide rates for both females and males in 2012 were among the lowest and lower ranges, respectively, in Northeast Asia. "Suicide rate" is defined as "Number of deaths from purposely self-inflicted injuries, expressed per 100,000 people in the reference population." 33 "Depth of the food deficit" is defined as "number of kilocalories needed to lift the undernourished from their status, holding all other factors constant." ${ }^{\prime 34}$ The depth of food deficit in Mongolia in 2013/2015 was 165 kilocalories per person, as compared with 344 kilocalories per person in North Korea, a country with chronic food shortage, and 4 kilocalories per person in Japan, the wealthiest country on a per capita basis in the region.

In conclusion, as far as human security and development challenges are concerned, there is much room for improvement in Mongolia. There is some likelihood that foreign migrants in Mongolia, unless they are among the privileged socio-economic circles, will experience some human security challenges that are indicated by prison population, homicide rate, and food deficit. To (dis)confirm this expectation, however, it is necessary to undertake empirical research, which is currently not available, at least in the English language.

\footnotetext{
Ibid.

31 Ibid.

32 Ibid.

33 Ibid.

34 Ibid.
} 


\section{Conclusion}

There is no doubt that Mongolian citizens will expand their search for economic, social, and cultural opportunities farther and wider throughout the world. However, Northeast Asian countries will remain the most important destinations for most Mongolian migrants because of geographic proximity, economic ties, and cultural affinity.

Due to its small economy, geographical remoteness, and restrictive immigration policy, Mongolia will likely remain a destination for only a limited number of international or labor migrants, refugees, human trafficking, and migrant smuggling. However, its expansive land and long frontiers will continue to challenge Mongolia's border control and immigration management. This is particularly the case because of the presence of significant numbers of border-crossing persons in Mongolia's neighboring countries, particularly China and Russia, and the dire political and economic situation in North Korea. Therefore, Mongolia cannot afford to ignore the regional trends described in this analysis.

Finally, the human security and development challenges Mongolian citizens face, both inside and outside of their country, are universal challenges. How the rest of the world, particularly how the other Northeast Asian countries, deal with these challenges will have important consequences for Mongolia's own development. If the neighboring countries can effectively deal with their problems, their emigration pressure will be reduced, thus diminishing immigration or transit pressure on Mongolia. 